\title{
Ameliorative effect of potassium sulphate on the growth and chemical composition of wheat (Triticum aestivum L.) in salt- affected soils
}

\author{
Z. Hussain ${ }^{1}$, R.A. Khattak ${ }^{2}$, M. Irshad ${ }^{3 *}$ and A.E. Eneji ${ }^{4}$ \\ ${ }^{1}$ Department of Development Studies, COMSATS Institute of Information Technology, Abbottabad, Pakistan. ${ }^{2}$ CECOS University \\ of Engineering and Emerging Sciences, Peshawar, Pakistan. ${ }^{3}$ Department of Environmental Sciences, COMSATS Institute of \\ Information Technology, Abbottabad, Pakistan. ${ }^{4}$ Department of Soil Science, University of Calabar, Nigeria. ${ }^{*}$ Corresponding \\ author:mirshad@ciit.net.pk.
}

\begin{abstract}
Potassium (K) and sodium (Na) coexist on the soil exchange complex and soil solution. Both cations may exert antagonistic or synergistic effects on mutual absorption and translocation within plants, particularly under saline and saline-sodic field conditions. This study investigated the role of $\mathrm{K}$ in alleviating the adverse effects of $\mathrm{Na}$ on wheat [Triticum aestivum (L), Iquilab-91] grown at two fields sites varying in salinity. The soils were moderately calcareous, weakly structured, mixed hyperthermic Typic Haplustepts. Site 1 was silty clay loam saline-sodic soil $\left(\mathrm{ECe}=4.23-9.45 \mathrm{dS} \mathrm{m}^{-1}\right)$ irrigated with groundwater with an $\mathrm{EC}_{\mathrm{iw}}$ value of $5.0 \mathrm{dSm}^{-1}$; Site 2 was clay loam saline soil $\left(E C e=3.2-5.0 \mathrm{dS} \mathrm{m}^{-1}\right)$ irrigated with groundwater with an ECiw of $2.4 \mathrm{dS} \mathrm{m}^{-1}$. Both sites were treated with 0,50 and $100 \mathrm{~kg} \mathrm{~K} \mathrm{ha}^{-1}$ applied as $\mathrm{K}_{2} \mathrm{SO}_{4}(41 \% \mathrm{~K})$ fertilizer. Significant increases of 14 and $30 \%$ in grain yield were measured at both sites, and 35 and 54\% increase in dry matter yields were observed in clay loam soil with the application of 50 and $100 \mathrm{~kg} \mathrm{~K} \mathrm{ha}^{-1}$. Potassium application decreased leaf [Na] and significantly increased [K]; the K:Na ratio showed a positive correlation with yield. Soil analysis showed significant increases in $[\mathrm{K}],[\mathrm{Na}]$ and $\mathrm{SAR}$, while $\mathrm{pH}, \mathrm{ECe}$ and $[\mathrm{Ca}+\mathrm{Mg}]$ were not affected by the $\mathrm{K}$ fertilizer. The $\mathrm{K}_{2} \mathrm{SO}_{4}$ increased crop yield by mitigating the adverse effect of $\mathrm{Na}$ and would thus be an effective source of $\mathrm{K}$ for crop production in saline and saline-sodic soils.
\end{abstract}

Keywords: Potassium sulphate, salt-affected soils, K: Na, leaf tissue composition, wheat

\footnotetext{
Abbreviations: ECiw, Electrical conductivity of irrigation water; Ece, Electrical conductivity of extract; K, Potassium; Ca, Calcium; Mg, Magnesium; Na, Sodium; SAR, Sodium adsorption ratio.
} 


\section{Introduction}

Salinity and sodicity are soil conditions that mostly occur in arid and semi-arid regions. In soils of arid zones, there is increased potential for hazardous accumulation of salts and the productivity of crops and plants is severely limited under such conditions. Reclamation of salt-affected soils through tillage, water, crop and chemical and/or fertilizer amendment practices is an increasingly important tool for improving crop productivity in many areas of the world (Jordan et al., 2004). The reclamation of these soils has been a driving force to turn marginally arable areas to agriculturally productive land by reducing levels of salinity and exchangeable Na.

Reduction in crop yield in saline and saline-sodic soils is associated with osmotic and specific ion effect and the degree and extent of the adverse effect is further exacerbated when saline water is used for irrigation (Bernstein, 1975; Sharma and Rao, 1998). Potassium (K) plays an important role in mitigating the adverse effects of high salt concentrations in soils (Garg and Gupta, 1998) and the stress tolerance of crops can be enhanced by optimizing $\mathrm{K}$ nutrition (Römheld and Kirkby, 2010). Potassium is known for its role in osmoregulation and stress mitigation, particularly in saline conditions (Cakmak, 2010). Under saline-sodic soil conditions, $\mathrm{K}$ interactions with $\mathrm{Na}$ in the distribution between soil solution and exchange phases and in subsequent absorption by roots and translocation within plants could be more critical.

Various studies with wheat have shown yield increases in responses to $\mathrm{K}$ fertilization in salt-affected soils. Genotypic differences for salt tolerance among the crop varieties are often explained on the variety's ability to exclude $\mathrm{Na}$ from root with least imbalance in K uptake (Schachtman and Liu, 1999). In these cases the salt tolerant varieties show a lower $\mathrm{Na}: \mathrm{K}$ ratio throughout a wide range of saline conditions (Sherif $e t$ al., 1998; Hussain and Khattak, 2005). Garg and Gupta (1998) correlated the maintenance of sufficient $\mathrm{Ca}$ and $\mathrm{K}$ concentrations and wider $\mathrm{K}: \mathrm{Na}$ ratios in the tissues under saline conditions with higher salt tolerance in mustard and suggested that such interactions deserve further investigation. The Egyptian wheat variety, Sakha 92 showed the best response to additional K at low and high $\mathrm{NaCl}$ concentrations (Sherif et al., 1998). The study also suggested that under low saline conditions, there is no need for $\mathrm{K}$ addition while at high level of salinity, application of $\mathrm{K}$ fertilizers could be useful to mitigate the adverse effects of salinity and/or sodicity on wheat growth in arid and semi-arid regions.

Most of the salinity-nutrient interaction studies have been conducted in sand or solution cultures (e.g, Grattan and Grieve, 1994; Grattan and Grieve, 1999; Silberbush and Ben-Asher, 2001) wherein the nutrient and salt concentrations were easily controlled. The ionic interactions in soilless system are simple and easily understood as compared to the complex system of soil and plants, particularly under saline environment (Khattak and Jarrell, 1988; Silberbush and Ben-Asher, 2001). Furthermore, the ratios of nutrients in solution culture are much different from those experienced by plants under field conditions (Grattan and Grieve, 1999), involving interactions and competition amongst different ions for adsorption sites on soil solid phase and for absorption sites on roots surfaces (Comerford, 2005; Fageria et al., 2011). Under field conditions, several factors such as CEC and amount and type of clay and organic matter affect the bio-availability of K (Tisdale et al., 1985). For, instance, fine textured soils have high CEC and hold high exchangeable $\mathrm{K}$ and may cause slow release of available $\mathrm{K}$. Cao et al. (1991) concluded that the application of K fertilizer increased the movement of $\mathrm{K}$ from soil to root-surface and improved the availability of $\mathrm{K}$ to wheat roots.

Salinity and fertility interaction experiments conducted under saline field environment showed an improved crop yield by addition of fertilizer to soil irrigated with saline water (Hussain and Khattak, 2005; Muhammad and Khattak, 2009). A more systematic research is 
required to observe the responses of crops to added $\mathrm{K}$ at the field level where extreme variability in salinity, soil texture and soil nutritional status is a norm. Here, we studied the effects of $\mathrm{K}$ fertilization on grain and dry matter yields, leaf tissue chemical composition and $\mathrm{K}: \mathrm{Na}$ ratio in relation to the physico-chemical properties of post-harvest saline and saline-sodic soils irrigated with saline groundwater of variable salinities.

\section{Materials and Methods}

Wheat [Triticum aestivum (L.), var. Inqilab-91] was grown on farmer's fields at two sites in Lachi (Kohat) area of Pakistan to evaluate the effect of potassium fertilizer in salt affected soils. Kohat District is $70 \mathrm{~km}$ from Peshawar. The area lies between longitude $32047^{\prime}$ and 340 5' North and latitude 690 53' and 720 1' East and falls in the semi-arid and sub-humid subtropical continental category of climate classification (Soil Survey of Pakistan, 2007). Lachi lies $33^{\circ} 23$ ' 43" N and the soils are reddish brown or yellowish brown, moderately calcareous, ranging from fine sandy loam to silty clay and clay loams. The soils are weakly structured and are classified as mixed hyperthermic Typic Haplustepts (Soil Survey of Pakistan, 2007). Parent rock material of the district Kohat is comprised of sandstone, limestone conglomerates, and salt rocks. The water reservoirs underlying the area are deep and contain poor quality, saline water with adverse effecton crop yield. Site 1 was a silty clay loam saline-sodic $\left(\mathrm{ECe}=4.2-9.5 \mathrm{dS} \mathrm{m}^{-1} ; \mathrm{pH} 1: 5=8.2-8.9\right)$ soil, irrigated with groundwater having ECiw $=5.0 \mathrm{dSm}^{-1}$. Site 2 was a clay loam saline $\left(\mathrm{ECe}=3.2-5.0 \mathrm{dS} \mathrm{m}^{-1} ; \mathrm{pH} 1: 5=7.6-\right.$ 8.1) soil, irrigated with groundwater having $\mathrm{ECiw}=2.4$ $\mathrm{dS} \mathrm{m} \mathrm{m}^{-1}$ (Table 1).

\subsection{Experimentation}

For each site, potassium was applied at 0,50 and 100 $\mathrm{kg} \mathrm{K} \mathrm{ha}{ }^{-1}$ in the form of potassium sulfate $\left(\mathrm{K}_{2} \mathrm{SO}_{4}\right)$ along with basal doses of urea $\left(120 \mathrm{~kg} \mathrm{~N} \mathrm{ha}^{-1}\right)$ and triple super phosphate (TSP) $\left(90 \mathrm{~kg} \mathrm{P} \mathrm{ha}^{-1}\right)$. The treatments
(K levels) were replicated three times at each site and arranged into a randomized complete block design. After 3-4 days of groundwater irrigation, fields were chisel-ploughed and harrowed. The experimental plot at each site was divided into 9 plots of $3 \times 3 \mathrm{~m} 2$ with plot to plot distance of $1 \mathrm{~m}$. Alleyways between plots were developed into water channels to provide irrigation. After the application of treatments, wheat cv. Inquilab 91 was sown in November at the seed rate of $120 \mathrm{~kg}$ $\mathrm{ha}^{-1}$ and harvested in April. The average rainfall during the cropping months was $400 \mathrm{~mm}$, while relatively higher mean rainfall was received during February and March. Mean monthly maximum temperatures ranges from 17.5 to $30.6 \mathrm{oC}$ and minimum from 5.2 to $12 \mathrm{oC}$ during the cropping period (Soil Survey of Pakistan, 2007a). All agronomic practices such as weeding and pest control were done according to local practices.

\subsection{Sampling and sample processing}

Groundwater samples were collected from the wells on the farmers' fields at both sites before irrigation. Precultivation and post harvest composite soil samples (0-30 $\mathrm{m}$ depth) from each site and youngest fully mature wheat leaf samples were also collected before harvesting.

After air-drying, the soil samples were gently crushed, sieved $(2 \mathrm{~mm})$ and stored in labeled polyethylene jars to avoid contamination. Plant leaves were washed with distilled water and oven-dried at $70 \mathrm{oC}$ for $48 \mathrm{~h}$, ground in Wiley-Mill and stored in labeled polyethylene jars for chemical analysis. The groundwater samples from both sites were collected in cleaned and rinsed plastic bottles, filtered through Whatman No. 40 filter paper and stored in a freezer.

Oven-dried leaf samples weighing $0.5 \mathrm{~g}$ were transferred into a flask, treated with $10 \mathrm{~mL}$ of concentrated $\mathrm{HNO}_{3}$ and left to digest overnight (Walsh and Beaton, 1977). After adding $4 \mathrm{~mL}$ of $\mathrm{HCIO}_{4}$, the flask was heated gently until the plant material digested. Upon cooling, contents were filtered through Whatman No. 40 filter paper and made to desired volume with distilled water. 
Table 1. Pre-sowing chemical properties of soils and groundwater at the two experimental sites

\begin{tabular}{|c|c|c|c|c|}
\hline Properties & Units & Range & Mean \pm St.Dev & \\
\hline & \multicolumn{3}{|c|}{ Site 1 (Silty clay loam, saline-sodic soil) } & Irrigation Water-1 \\
\hline $\mathrm{pH}_{(1: 5)}$ & - & $8.17-8.85$ & $8.64 \pm 0.26$ & 8.20 \\
\hline $\mathrm{EC}_{\mathrm{e}}$ & $\mathrm{dS} \mathrm{m}^{-1}$ & 4.23-9.45 & $5.55 \pm 1.56$ & 5.02 \\
\hline $\mathrm{Na}$ & mmol $(+) \mathrm{L}^{-1}$ & $32.6-64.2$ & $39.5 \pm 9.81$ & 27.65 \\
\hline $\mathrm{Ca}+\mathrm{Mg}$ & $\operatorname{mmol}(+) \mathrm{L}^{-1}$ & $14.0-35.8$ & $20.6 \pm 6.76$ & 16.90 \\
\hline $\mathrm{K}$ & $\operatorname{mmol}(+) \mathrm{L}^{-1}$ & $0.23-0.59$ & $0.36 \pm 0.13$ & 0.07 \\
\hline \multirow[t]{2}{*}{ SAR } & - & $10.4-15.2$ & $12.4 \pm 1.43$ & 9.51 \\
\hline & \multicolumn{3}{|c|}{ Site 2 (Clay loam, saline soil) } & Irrigation Water-2 \\
\hline $\mathrm{pH}_{(1: 5)}$ & - & $7.62-8.06$ & $7.85 \pm 0.16$ & 8.10 \\
\hline $\mathrm{EC}_{\mathrm{e}}$ & $\mathrm{dS} \mathrm{m}^{-1}$ & $3.20-5.00$ & $4.24 \pm 0.58$ & 2.40 \\
\hline $\mathrm{Na}$ & $\operatorname{mmol}(+) \mathrm{L}^{-1}$ & $11.5-22.3$ & $15.6 \pm 3.73$ & 13.50 \\
\hline $\mathrm{Ca}+\mathrm{Mg}$, & $\operatorname{mmol}(+) \mathrm{L}^{-1}$ & $18.8-33.0$ & $27.2 \pm 5.20$ & 9.50 \\
\hline K & mmol (+) $\mathrm{L}^{-1}$ & $0.13-0.23$ & $0.15 \pm 0.04$ & 0.07 \\
\hline SAR & - & $3.38-7.00$ & $4.22 \pm 1.19$ & 6.19 \\
\hline
\end{tabular}

\subsection{Analyses of soil, water and plant samples}

Soil texture was determined using hydrometric method (Bouyoucos, 1962; Gee and Bauder, 1986). Saturated soil paste was prepared adding distilled water to $250 \mathrm{~g}$ soil in a plastic beaker while stirring with a spatula. Saturated soil paste was kept overnight to allow salt dissolution and equilibration (Richards, 1954), then transferred to the suction funnel with filter paper in place and vacuumed. The extract was collected in labeled polyethylene bottles for analysis. The $\mathrm{pH}$ of soil suspension with soil:water ratio of 1:5 and water samples was determined using the 105 Ion analyzer pH meter (McLean, 1982; Thomas, 1996). Electrical conductivity (EC) was measured using a digital EC meter, Wiss. Techn. Werkstatten (WTW) D12 Weilheim (Rhoades, 1982).

Soil saturation extracts, plant and water samples were analyzed for $\mathrm{Na}$ and $\mathrm{K}$ concentrations using a PerkenElmer flame photometer model No.2380. 
The concentrations of $\mathrm{Na}$ and $\mathrm{K}$ were calculated in mmol (+) L $\mathrm{L}^{-1}$ (Richards, 1954). For determination of $\mathrm{Ca}$ and $\mathrm{Mg}, 3 \mathrm{~mL}$ of soil saturation extract, water or plant samples was taken into a $15 \mathrm{~mL}$, wide mouthed porcelain crucible and $1 \mathrm{~mL}$ of $\mathrm{NH}_{4} \mathrm{CI}$ plus $\mathrm{NH}_{4} \mathrm{OH}$ and few drops Eriochrome Black-T were added. The sample was titrated against $0.01 \mathrm{~N}$ EDTA until the color was changed from wine red to blue or green (Richards, 1954). Using values of $\mathrm{Na}$ and $\mathrm{Ca}+\mathrm{Mg}$ concentrations $\left[\mathrm{mmol}(+) \mathrm{L}^{-1}\right]$ in soil saturation extracts and water samples, the SAR of the soils and water was calculated using the formula (Richards, 1954):

$$
S A R=\frac{[\mathrm{Na}]}{\sqrt{\frac{[\mathrm{Ca}+\mathrm{Mg}]}{2}}}
$$

Data were subjected to an analysis of variance using the statistical package of MSTATC program (Steel and Torrie, 1980). We used sites and $\mathrm{K}$ rates as factors and treatment means were compared using Duncan's multiple range test at the $5 \%$ level of probability.

\section{Results and Discussion}

A summary of analysis of variance showing the F-ratios for wheat grain and dry matter yield, chemical composition of leaf tissue and post-harvest soil saturated extracts is given in Table 2 .

\subsection{Initial (pre-cultivation) chemical properties of soil and water}

Chemical analyses of soil and water samples collected before sowing showed marked differences between the properties of the two sites (Table 1). Site 1 had higher $\mathrm{pH} 1: 5, \mathrm{ECe}$, and SAR than Site 2. Site 1 also had higher K level $\left[0.23\right.$ to $\left.0.59 \mathrm{mmol}(+) \mathrm{L}^{-1}\right]$ in soil saturation extracts than Site $2[0.13$ to $0.23 \mathrm{mmol}$ (+) $\left.\mathrm{L}^{-1}\right]$. The ground water at Site 1 with relatively elevated salinity and sodicity might be responsible for the higher $\mathrm{EC}_{\mathrm{e}}, \mathrm{Na}, \mathrm{K}$ and $\mathrm{SAR}$ for the site.

\subsection{Wheat response to $K$ fertilizer}

The addition of $\mathrm{K}$ significantly increased grain and dry matter yield of wheat at both sites (Table 2). The two sites produced significantly $(p<0.01)$ different dry matter yields but showed non-significant difference in grain yields. The soil and $\mathrm{K}$ interaction had marked effect on dry matter yield. The increases in grain yield observed at both sites with the given rates of $\mathrm{K}$ were similar (14 and 30\%) but the increases (35 and 54\%) in dry matter yield were higher in clay loam (Site 2) than the 7 and $29 \%$ increases observed in the silty clay loam soil (Site 1) [Table 3]. The poor crop yield of sodic soils is often associated with their low infiltration rates and restricted aeration because of high exchangeable $\mathrm{Na}$ (Jayawardane and Chan, 1994). Hence, the lower ECe, [Na] and ECiw in Site 2 than Site 1 explains the better wheat growth and dry matter yields in Site 2 .

Potassium deficiency in plants reduced the growth rate (Mengel and Kirkby, 2001) but increased supplies of $\mathrm{K}$ make up for $6 \%$ of the plant dry matter (Leigh and Jones, 1984). In this study, the increased leaf tissue $[\mathrm{K}]$ induced by the added $\mathrm{K}$ was positively correlated with grain and dry matter yields of wheat at both sites [Figure1 (a) and (b)]. The screening processes of salt tolerance of crops, as suggested in Munns (2002) might be due to the concept of two-way growth response to salinity. The growth reduction in the first phase is due to salts in rooting media creating osmotic stress. The second phase growth reduction involves salt accumulation in leaves resulting in poor crop yields. The application of $\mathrm{K}$ in the present study improved wheat yield which might be due to increased salt tolerance as determined by the mechanism of salt exclusion associated with selectivity of $\mathrm{K}$ uptake by roots and preferential loading of $\mathrm{K}$ rather than $\mathrm{Na}$ in xylem (Jeschke, 1984; Munns, 2002). Previous studies confirmed the biochemical role of $\mathrm{K}$ in plant nutrition and osmoregulation in enhancing tolerance and mitigating the adverse effects of high salt concentrations in soils, thereby increasing crop yields (Garg and Gupta, 1998; Schachtman and Liu, 1999; Sherif et al., 1998). 
Various studies showed reductions in wheat yields with increasing salinity of irrigation waters. Sharma and Rao (1998) reported 4.2 to $22.2 \%$ yield reduction in wheat with increasing salinities from 6 to $18.8 \mathrm{dS}$ $\mathrm{m}^{-1}$ of irrigation water. In our case, however, saline irrigation produced no significant change in yield which could be associated with the application of $\mathrm{K}$ and higher electrolyte concentrations (EC) of irrigation water which minimized the adverse effect of $\mathrm{Na}$.

Table 2. Summary analysis of analysis of variance showing F-ratios for wheat grain and dry matter yield, chemical composition of leaf tissue and post-harvest soil saturated extracts of silty clay loam saline-sodic (Site 1) and clay loam saline (Site 2) soils

\begin{tabular}{|c|c|c|c|c|c|c|c|c|c|c|c|c|}
\hline \multirow{3}{*}{$\begin{array}{l}\text { Source of } \\
\text { variation }\end{array}$} & \multicolumn{2}{|c|}{ Wheat yield } & \multicolumn{4}{|c|}{ Leaf tissue } & \multicolumn{6}{|c|}{ Post-harvest soil saturation extract } \\
\hline & \multicolumn{12}{|c|}{ Variables Analyzed } \\
\hline & Grain & Dry matter & K & $\mathrm{Na}$ & $\mathrm{Ca}+\mathrm{Mg}$ & $\mathrm{K}: \mathrm{Na}$ & $\mathrm{EC}_{\mathrm{e}}$ & K & $\mathrm{Na}$ & $\mathrm{Ca}+\mathrm{Mg}$ & SAR & $\mathrm{Na}: \mathrm{K}$ \\
\hline $\mathrm{K}$ & $14.3^{* *}$ & $38.7^{* * *}$ & $11.7^{* *}$ & $50.0^{* * *}$ & $0.66^{\mathrm{NS}}$ & $47.8^{* * *}$ & $2.4^{\mathrm{NS}}$ & $46.3^{* * *}$ & $7.62^{*}$ & $0.45^{\mathrm{NS}}$ & $5.84^{*}$ & $7.66^{*}$ \\
\hline Soil & $1.11^{\mathrm{NS}}$ & $94.2^{*}$ & $158.3^{* *}$ & $27.0^{*}$ & $4.0^{\mathrm{NS}}$ & $35.8^{*}$ & $56.4^{*}$ & $86.5^{*}$ & $62.1^{*}$ & $77.5^{*}$ & $19.2^{*}$ & $0.69^{\text {NS }}$ \\
\hline
\end{tabular}

$*, * *, * *=$ Significant at $p<0.05,0.01$ and 0.001 , respectively and NS= Not-significant

\subsection{Chemical composition of wheat leaf tissue}

The application of $\mathrm{K}$ significantly affected the leaf tissue $[\mathrm{K}]$ and $[\mathrm{Na}]$ and $\mathrm{K}: \mathrm{Na}$ (Table 2) but the two soils behaved differently. The soil $\mathrm{x} \mathrm{K}$ interaction had significant effect on $[\mathrm{Na}]$ and $[\mathrm{K}]$ and nonsignificant on $[\mathrm{Ca}+\mathrm{Mg}]$ and $\mathrm{K}: \mathrm{Na}$ ratio.

Consistent decreases in leaf tissue $[\mathrm{Na}]$ and increases in [K] with addition of 50 and $100 \mathrm{~kg} \mathrm{~K}$ $\mathrm{ha}^{-1}$ at both the sites were observed (Table 3 ). With addition of $\mathrm{K}$, leaf tissues [Na] decreased by 14.5 and $38.3 \%$ at Site 1 , and 37.2 and $63.8 \%$ at Site 2 ; the increased leaf tissue [K] showed positive correlation with grain yield of wheat at Site $1\left(\mathrm{R}^{2}\right.$ $=0.73)$ and Site $2\left(\mathrm{R}^{2}=0.80\right)$ as shown in Figure 1(a). The dry matter yield also showed positive correlation $\left(\mathrm{R}^{2}=0.92\right.$ and 0.71 for Site 1 and Site 2) with tissue $\mathrm{K}$ [Figure 1(b)]. The uptake of $\mathrm{K}$ by wheat reduced $\mathrm{Na}$ uptake resulting in significant $(p<0.01)$ increase in $\mathrm{K}$ : Na ratio of leaf tissues which might have enhanced grain yield by lowering $\mathrm{Na}$ toxicity. The relationship between grain yield with $\mathrm{K}: \mathrm{Na}$ was better in silty clay loam soil $\left(\mathrm{R}^{2}=0.73\right)$ than clay loam soil $\left[\left(\mathrm{R}^{2}=0.49\right.\right.$, Figure $\left.2(\mathrm{a})\right]$. The increase in leaf $\mathrm{K}: \mathrm{Na}$ ratio was significantly correlated with dry matter yield at Site $1\left(\mathrm{R}^{2}=0.91\right)$ and Site $2\left(\mathrm{R}^{2}=\right.$ 0.62 ) as shown in Figure 2(b). 
Table 3. Wheat grain and dry matter yields, composition of leaf tissue and post-harvest soils as affected by $\mathrm{K}$ application to silty clay loam saline-sodic (Site 1) and clay loam saline (Site 2) soils

\begin{tabular}{|c|c|c|c|c|c|c|c|c|c|c|c|c|c|}
\hline \multirow{2}{*}{$\begin{array}{c}\text { Treatments } \\
\mathrm{K}\end{array}$} & \multicolumn{2}{|c|}{ Wheat yield } & \multicolumn{4}{|c|}{ Leaf tissue composition } & \multicolumn{7}{|c|}{ Post-harvest soil composition } \\
\hline & Grain I & Pry matter & $\mathrm{K}$ & $\mathrm{Na}$ & $\mathrm{Ca}+\mathrm{Mg}$ & $\mathrm{K}: \mathrm{Na}$ & $\mathrm{pH}_{(1: 5)}$ & $\mathrm{EC}_{\mathrm{e}}$ & K & $\mathrm{Na}$ & $\mathrm{Ca}+\mathrm{Mg}$ & SAR & $\mathrm{Na}: \mathrm{K}$ \\
\hline $\mathrm{kg} \mathrm{ha}^{-1}$ & \multicolumn{2}{|c|}{$\mathrm{Mg} \mathrm{ha}^{-1}$} & \multicolumn{4}{|c|}{$\mathrm{mmol} \mathrm{kg}^{-1}$} & & $\mathrm{dS} \mathrm{m}^{-1}$ & \multicolumn{4}{|c|}{ 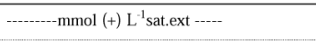 } & \\
\hline \multicolumn{14}{|c|}{ Site 1 (silty clay loam saline-sodic soil) } \\
\hline 0 & 2.00 & $9.10 \mathrm{~d}$ & $420.3 \mathrm{c}$ & $54.5 \mathrm{bc}$ & 1433 & 7.79 & 7.81 & $4.60 \mathrm{~b}$ & 0.20 & 21.7 & 24.5 & 6.16 & 108.2 \\
\hline 50 & 2.28 & $9.77 \mathrm{~d}$ & $527.2 \mathrm{~b}$ & $46.6 \mathrm{~cd}$ & 1533 & 11.4 & 7.88 & $5.58 \mathrm{a}$ & 0.28 & 29.8 & 24.7 & 8.50 & 105.7 \\
\hline 100 & 2.60 & $11.7 \mathrm{c}$ & $668.4 \mathrm{a}$ & $33.6 \mathrm{e}$ & 1633 & 19.9 & 7.86 & $5.45 \mathrm{ab}$ & 0.34 & 30.6 & 24.8 & 8.67 & 90.0 \\
\hline \multicolumn{14}{|c|}{ Site 2 (clay loam saline soil) } \\
\hline 0 & 2.13 & $9.80 \mathrm{~d}$ & $428.6 \mathrm{c}$ & 89.7 a & 1500 & 4.78 & 7.99 & $1.84 \mathrm{c}$ & 0.07 & 10.3 & 6.17 & 5.91 & 147.9 \\
\hline 50 & 2.42 & $13.2 \mathrm{~b}$ & $474.3 \mathrm{bc}$ & $62.6 \mathrm{~b}$ & 1533 & 7.62 & 7.88 & $1.63 c$ & 0.11 & 11.1 & 5.00 & 7.06 & 99.7 \\
\hline 100 & 2.62 & $15.1 \mathrm{a}$ & $499.1 \mathrm{bc}$ & $36.1 \mathrm{de}$ & 1767 & 14.2 & 7.90 & $1.69 \mathrm{c}$ & 0.18 & 11.9 & 6.67 & 6.62 & 67.0 \\
\hline Soils & \multicolumn{13}{|c|}{ - } \\
\hline Site 1 & $2.29 \mathrm{~b}$ & $10.2 \mathrm{~b}$ & $538.5 \mathrm{a}$ & $44.9 \mathrm{~b}$ & $1533 \mathrm{~b}$ & $13.0 \mathrm{a}$ & 7.85 & $5.21 \mathrm{a}$ & 0.27 a & $27.4 \mathrm{a}$ & $24.7 \mathrm{a}$ & 7.78 a & 101.3 \\
\hline Site 2 & $2.39 \mathrm{a}$ & $12.7 \mathrm{a}$ & $467.3 \mathrm{~b}$ & $62.8 \mathrm{a}$ & 1600 a & $8.88 \mathrm{~b}$ & 7.92 & $1.72 \mathrm{~b}$ & $0.12 \mathrm{~b}$ & $11.1 \mathrm{~b}$ & $5.94 \mathrm{~b}$ & $6.31 \mathrm{~b}$ & 105.5 \\
\hline $\mathrm{K}\left(\mathrm{kg} \mathrm{ha}{ }^{-1}\right)$ & \multicolumn{13}{|c|}{ 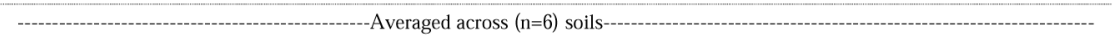 } \\
\hline 0 & $2.07 \mathrm{c}$ & $9.45 \mathrm{c}$ & $424.3 \mathrm{c}$ & 72.1 a & 1467 & $6.29 \mathrm{c}$ & 7.90 & 3.22 & $0.14 \mathrm{c}$ & $16.0 \mathrm{~b}$ & 15.4 & $6.04 \mathrm{~b}$ & $128.0 \mathrm{a}$ \\
\hline 50 & $2.35 \mathrm{~b}$ & $11.5 \mathrm{~b}$ & $500.7 \mathrm{~b}$ & $54.6 \mathrm{~b}$ & 1533 & $9.49 \mathrm{~b}$ & 7.88 & 3.61 & $0.20 \mathrm{~b}$ & $20.5 \mathrm{a}$ & 14.8 & $7.45 \mathrm{a}$ & $102.7 \mathrm{ab}$ \\
\hline 100 & $2.61 \mathrm{a}$ & $13.4 \mathrm{a}$ & $583.8 \mathrm{a}$ & $34.8 \mathrm{c}$ & 1700 & $17.1 \mathrm{a}$ & 7.88 & 3.57 & $0.26 \mathrm{a}$ & $21.3 \mathrm{a}$ & 15.8 & $7.65 \mathrm{a}$ & $79.5 \mathrm{~b}$ \\
\hline
\end{tabular}

$\uparrow$ Means followed by similar letters in a column are non-significant at $p<0.05$

Since the total $\mathrm{Na}$ accumulated [concentration $\mathrm{x} \mathrm{DM}$ yield, data not shown] also decreased with addition of $\mathrm{K}$, the decrease in $[\mathrm{Na}]$ in the wheat leaf tissue could not be related to the dilution effect commonly associated with yield increases (Jarrell and Beverly, 1981).

The chemical composition of soil saturation extracts (Table 3) may also help to explain the variation in the crop yield. The soil at Site 2 had much lower $[\mathrm{K}]$ in saturation extracts $\left[0.07\right.$ to $\left.0.18 \mathrm{mmol}(+) \mathrm{L}^{-1}\right]$ than the soil of Site $1\left[0.20\right.$ to $\left.0.34 \mathrm{mmol}(+) \mathrm{L}^{-1}\right]$. Such lower [K] might be a growth limiting factor at Site 2, but not at Site 1. This observation is in agreement with those of Bernstein et al. (1975) that plant growth is promoted more if the most limiting factor is relieved.
With the addition of $\mathrm{K}_{2} \mathrm{SO}_{4}$, the soil was able to replenish the $\mathrm{K}$ required and the plant uptake was adequate at Site 2 and hence the better crop growth. In the present study, the $[\mathrm{K}]$ in saturated soil extracts was positively correlated with tissue $[\mathrm{K}]\left(\mathrm{R}^{2}=0.74\right.$, Site 1 and $\mathrm{R}^{2}=0.59$, Site 2) as shown in Figure 3. Kemmler (1983) reported that wheat and other cereal crops frequently require about the same amount of $\mathrm{K}$ as $\mathrm{N}$ but the need for $\mathrm{K}$ might exceed that of $\mathrm{N}$ in some crop growth instances. The total $\mathrm{K}$ uptake is also influenced by soil available $\mathrm{K}$ level, amount of applied $\mathrm{K}$ fertilizer, soil fertility level, soil type and crop varieties. This leads to the conclusion that Site 2 being clay loam has stronger affinity for $\mathrm{K}$ adsorption (Khattak et al., 2002) and as such the addition of $\mathrm{K}$ fertilizers was more beneficial. 
(a)

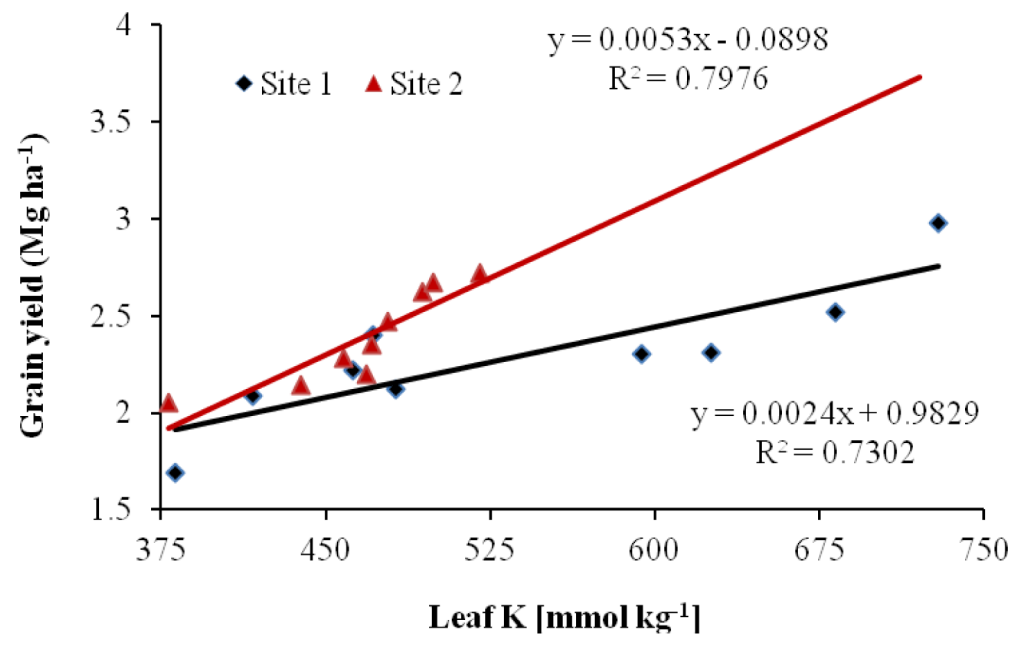

(b)

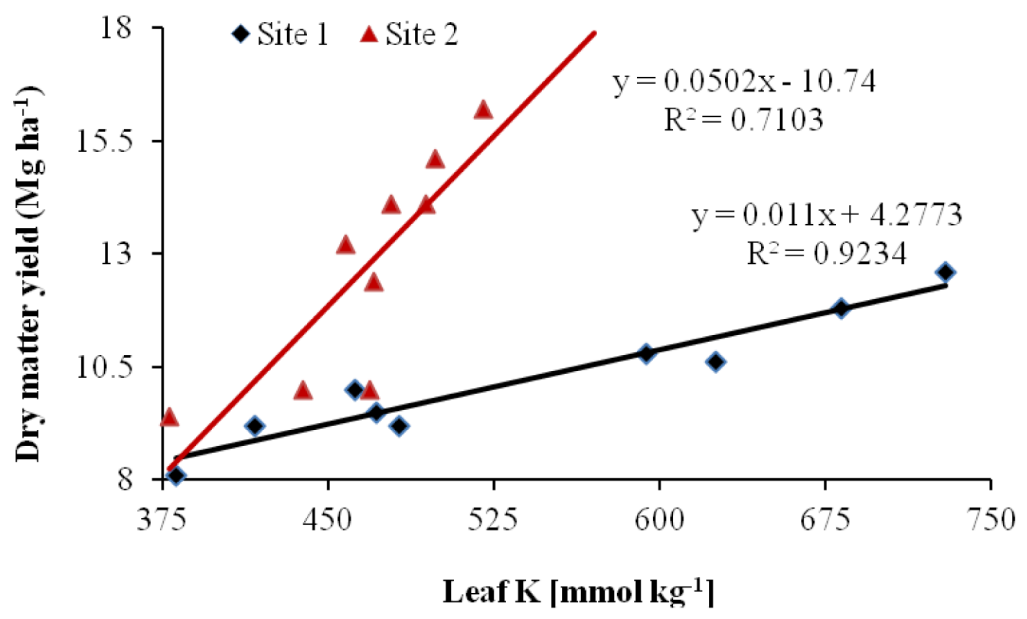

Figure 1. Regression of grain (a) and dry matter (b) yields of wheat versus leaf $[\mathrm{K}]\left(\mathrm{mmol} \mathrm{kg}^{-1}\right)$ in silty clay loam saline-sodic (Site 1) and clay loam saline soil (Site 2). 

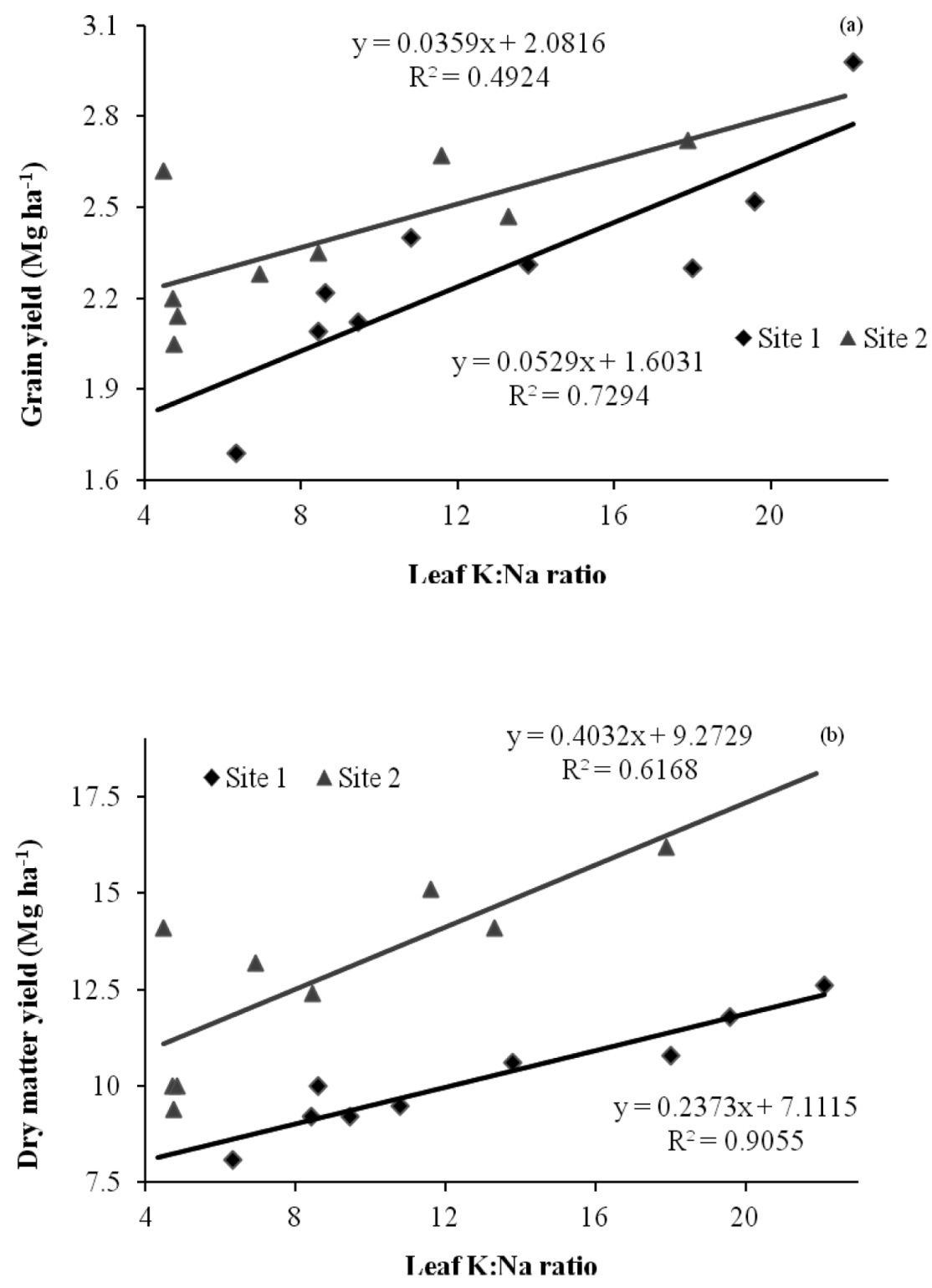

Figure 2. Regression of grain (a) and dry matter (b) yields of wheat versus leaf K:Na ratio in silty clay loam salinesodic soil (Site 1) and clay loam saline soil (Site 2). 


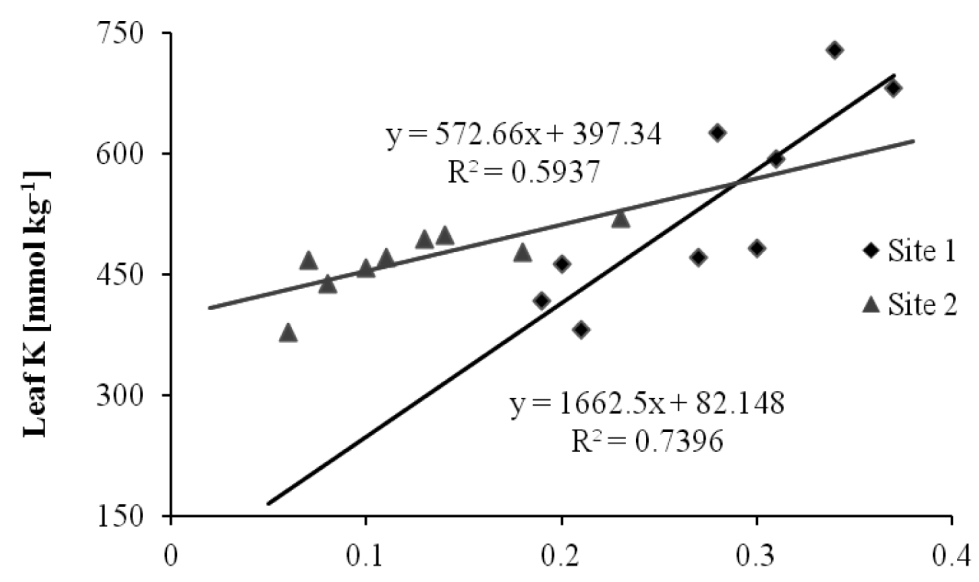

Soil $\mathbf{K}\left[\mathbf{m m o l}(+) \mathbf{L}^{-1}\right]$ Sat. Ext.

Figure 3. Relationship between soil saturation extract $[\mathrm{K}]$ and wheat leaf $[\mathrm{K}]$ in silty clay loam saline-sodic soil (Site 1) and clay loam saline soil (Site 2)

Although $[\mathrm{Ca}+\mathrm{Mg}]$ was little affected, the uptake of both cations tended to increase with $\mathrm{K}$ addition in both soils, and might have improved shoot growth due to reductions in $\mathrm{Na}$ :Ca ratio as suggested in Grieve and Fugiyama (1987). Similarly, Kinraide (1999) reported that wheat tissue $[\mathrm{Na}$ ] was reduced by $\mathrm{Ca}$ and $\mathrm{K}$ in the root zone and tissue $[\mathrm{K}]$ was enhanced by $\mathrm{Ca}$ and $\mathrm{Na}$.

Various other studies have shown the positive trends of plants selectivity for $\mathrm{K}$ over $\mathrm{Na}$ and the increases in yields with increasing $[\mathrm{K}]$ due to increased $\mathrm{K}: \mathrm{Na}$ ratios. For example, Chhipa and Lal (1995) reported that $\mathrm{K}: \mathrm{Na}$ ratio $>6.67$ in grain and $>2.50$ in straw indicated the tolerance of wheat to sodicity. Similarly, Salam et al. (1999) concluded that inter-varietal variation in salt tolerance in wheat was controlled by genes and that the K:Na ratio of the youngest leaf could be used to screen for salt tolerance. Also, $\mathrm{Na}$ exclusion from wheat roots correlated well with salt tolerance of plants in the saline-sodic soils (Munns and James 2003). Therefore, the better grain and dry matter yields of wheat under the saline and saline-sodic soil conditions in the present study could be associated with higher K:Na ratios.

\subsection{Post harvest soil solution concentrations}

The addition of $\mathrm{K}$ did not significantly affect the post harvest soil $\mathrm{pH}(1: 5), \mathrm{ECe}$ and $[\mathrm{Ca}+\mathrm{Mg}]$, however, $[\mathrm{K}]$ and $[\mathrm{Na}]$ tended to increase in soil saturation extracts of both sites (Table 3). A comparison of soil chemical composition of both site and with the initial (pre-sowing) composition revealed that the ECe and concentrations of all the cations were lower in the saline soil of Site 2 after harvesting than Site 1, which explains the relatively higher yield at Site 2 .

The $[\mathrm{K}]$ in soil saturation extracts of Site 1 increased more than that of Site 2. Moreover, the groundwater used for irrigation had higher $\mathrm{K}$ concentrations at Site 1 than Site 2 which might have profound effect on K accumulation, hence the Na:K ratios in soil at Site 2 
showed much better correlation $\left(\mathrm{R}^{2}=0.75\right)$ than the soil at Site $1\left(\mathrm{R}^{2}=0.23\right)$ (Table 2$)$ with $[\mathrm{K}]$ in saturated extracts. The higher $\mathrm{K}$ concentration in soil ensured $\mathrm{K}$ availability and supported relatively equivalent grain yield at Site 1 .

As compared to control, the SAR values increased significantly with the addition of $\mathrm{K}_{2} \mathrm{SO}_{4}$ in the silty clay loam and non-significantly in the clay loam soil. The $[\mathrm{Na}]$ in saturated extracts increased substantially in the silty clay loam and did not change in the clay loam which explains the observed variation in SAR. However, SAR values decreased substantially (5.91$8.61)$ with cropping as compared to pre-sowing values (10.4-14.2) (Table 1). The [Ca+Mg] did not change with addition of $\mathrm{K}$ but was higher in silty clay loam and lower in clay loam than pre-sowing values (Table 1).

The chemical analysis of post-harvest soil showed some positive changes when compared with the initial (pre-sowing) soil analysis. The addition of $\mathrm{K}$ tended to increase $[\mathrm{K}]$ and $[\mathrm{Na}]$ in soil saturation extracts but overall $[\mathrm{Na}], \mathrm{Na}: \mathrm{K}$ ratios and SAR decreased when compared to initial values. The increases in $[\mathrm{Na}]$ caused by addition of $\mathrm{K}_{2} \mathrm{SO}_{4}$ could be associated with displacement of Na by K into solution (Richards 1954; Levy and Feigenbaum 1996) and formation of soluble complexes which pulled $\mathrm{Na}$ into solution as soluble $\mathrm{Na}_{2} \mathrm{SO}_{4}{ }^{0}$ and $\mathrm{NaSO}_{4}^{-}$(Spark, 1995).

In soil saturation extracts where the $\mathrm{Na}: \mathrm{K}$ ratio was less than 4:1, the measured ESP and SAR were considerably lower than usually observed in high $\mathrm{Na}$ soils (Robbins, 1984). For soils in the present study, the $\mathrm{Na}: \mathrm{K}$ ratios in soil saturation extracts were lower than the reported ratio (Robbins, 1984) even after K addition. According to Qadir et al. (2005), during the process of phyto-remediation of salt affected soils, the roots of crops increased the dissolution of calcite resulting to enhanced levels of $\mathrm{Ca}$ in soil solution to replace $\mathrm{Na}$ from the cation exchange complex.

The irrigation water used at Site 1 had high EC and SAR than that of Site 2 (Table 1). The higher salt concentrations in irrigation water of Site 1 added more salts to the soil. However, the lower concentrations of most of the cations in post-harvest soil might be due to leaching promoted by the silty clay loam texture of soils and higher electrolyte levels in irrigation waters at Site 1 . The relatively higher average rainfall during the months of January - March (Soil Survey of Pakistan, 2007a) might also have contributed to leaching of most cations. Abbott et al. (1996) reported that use of saline water for irrigation increased soil salinity. However, it was possible to improve soil salinity and crop production by means of irrigation with saline water at certain growth stages (Ferdous et al. 1997). Continuous irrigation with such waters might reduce sodicity hazard through the replacement of the $\mathrm{Na}$ with K (Levy and Torrento, 1995).

The present study suggested that $\mathrm{K}_{2} \mathrm{SO}_{4}$ addition could promote crop yield under saline and salinesodic conditions. Under such soil conditions, closure of stomata and inhibited photosynthetic activity due to lower $\mathrm{K}$ nutritional status induces the formation of toxic oxygen radicals (Cakmak 2005) and as such a higher K supply can counteract this effect under saline conditions (Abogadallah et al., 2010). Addition of $\mathrm{K}$ can mitigate the adverse effect of $\mathrm{Na}$ induced by saline and saline-sodic waters and thereby improve crop growth (Ali et al., 1999). However, focus must not be only on lowering of $\mathrm{Na}$ accumulation in shoot tissue as a measure of mitigation of salt stress as suggested in Shabala and Cuin (2008) but rather on K homeostasis maintaining a high $\mathrm{K}: \mathrm{Na}$ ratio (Rubio et al., 2010) by preventing $\mathrm{K}$ losses by $\mathrm{Na}$ and/or $\mathrm{Na}$-induced $\mathrm{Ca}$ deficiency.

The amelioration of saline-sodic soils due to improved $\mathrm{K}$ utilization with press mud application decreased the adverse effect of [Na] on plant (Muhammad and Khattak, 2009). Salt tolerant wheat lines showed higher K:Na ratios in leaf tissues which promoted crop yields in saline and saline-sodic soils (Hussain and Khattak, 2005). In the present study, a high K:Na ratio in leaf tissues was indicative of reduced uptake of $\mathrm{Na}$ from soil solution and/or increased uptake of K, thus 
minimizing its adverse effects. While these studies suggested the positive effects of $\mathrm{K}$ fertilization on soils and plants, more detailed studies are needed to explore the effects of associated anions such as $\mathrm{SO}_{4}, \mathrm{NO}_{3}$ and $\mathrm{PO}_{4}$ on minimizing the adverse effect of $\mathrm{Na}$ and $\mathrm{Cl}$ in saline-sodic soils irrigated with saline water.

\section{Conclusions}

The yields of wheat significantly increased with the application of $\mathrm{K}$ fertilizer. The better yield and growth were paralleled by increased K: Na ratio at both sites, which also indicates an improvement in salt tolerance of the crop. The application of $\mathrm{K}_{2} \mathrm{SO}_{4}$ could promote crop yield and mitigate the adverse effect of $\mathrm{Na}$ and would thus be an effective approach to enhanced crop production in saline and saline-sodic soils.

\section{Acknowledgements}

The authors thankfully acknowledge the funding by Higher Education Commission (HEC) of Pakistan through the first author.

\section{References}

Abbott, C.L.D., El-Quosy, E.D., Pearce, G.R., Bayoumi, M.N. 1996. Soil salinity levels due to drainwater reuse in the Nile Delta (New Delhi, India). Int. Comm. Irrig. Drainage (ICID), p.p. 523-533.

Abogadallah, G.M., Serag, M.M., Quick, W.P. 2010. Fine and course regulation of reactive oxygen species in the salt tolerant mutants of barnyard grass and their wild-type parents under salt stress. Physiol. Plant. 138, 60-73.
Ali, C.K., Javed, M., Javaid, M.A. 1999. Growth promotion of wheat by potassium application in saline soils. J. Ind. Soc. Soil Sci. 47, 510-513.

Bernstein, L. 1975. Effects of salinity and sodicity on Plant growth. Annual Review Phytopathol. 13, 295-312.

Bernstein, L., Francois, L.E., Clark, R.A. 1974. Interactive effects of salinity and fertility on the yield of grains and vegetables. Agron. J. 66, 412421.

Bouyoucos, G.J. 1962. Hydrometer method improved for making particle size analysis of soils. Agron. J. 54, 464-465.

Cakmak, I. 2005. The role of potassium in alleviating detrimental effects of abiotic stresses in plants. J. Plant Nutr. Soil Sci. 168, 521-530.

Cakmak, I. 2010. Potassium for better crop production and quality. Plant Soil. 335, 1-2.

Cao, Y.P., Xii, Y.T., Li, X.L. 1991. The distribution of potassium in rhizosphere I wheat. Acta Agric. 17(2), 69-74.

Chhipa, B.R., Lal, P. 1995. Na/K ratios as the basis of salt tolerance in wheat. Austr. J. Agric. Res. 46(3), 533-539.

Comerford, M.B. 2005. Soil factors affecting nutrient bioavailability, vol. 181, in BassiriRad, H. (Ed.), Ecological studies, Nutrient Acquisition by PlantsAn Ecological Perspective. (C) Springer-Verlag, Berlin Heidelberg.

Ferdous, A., Karadsheh, I., Shatanawi, N. 1997. Barley response to salinity stress under arid conditions of Jordan, in: Hamdy, A. (Ed.), Centre International de Haute Etudes Agromiquest Meditteraneennes (CIHEAM), France, pp. 95-108. 
Fageria, N.K., Baligar, V.C., Jones, C.A. 2011. Nutrient flux in soil-plant system: Growth and mineral nutrition in wheat crops, third ed. CRC Press, pp. 57-79.

Garg, B.C., Gupta, I.C. 1998. Physiology of salt tolerance of arid-zone crops. IV. Rapeseed and Indian mustard, Central Arid Zone Research Institute, Jodhpure, India. Curr. Agric. 22, 1-2.

Gee, G.W., Bauder, J.W. 1986. Particle size analysis, in: Klute, A. (Ed.), Methods of Soil Analysis, Part 1, second ed. New York, USA, pp. 383-411

Grattan, S.R., Grieve, C.M. 1994. Mineral nutrition acquisition and response by plants grown in saline environments, in: Pessarakli, M. (Ed.), Handbook of Plant and Crop Stress. Marcel Dekker, New York, pp. 203-226.

Grattan, S.R., Grieve, C.M. 1999. Salinity-mineral nutrient relations in horticultural crops. Sci. Hort. 78, 127-157.

Grieve, C.M., Fugiyama, H. 1987. The response of two rice cultivars to external $\mathrm{Na}$ :Ca ratio. Plant Soil. $103,245-250$.

Hussain, Z., Khattak, R.A. 2005. Comparison of the performance of four wheat lines in salt-affected soils. Soil Environ. 24 (2), 128-132.

Jarrell, W.M., Beverly, R.B. 1981. The dilution effect in plant nutrition studies. Adv. Agron. 34, 197-224.

Jayawardane, N. S., Chan, K. Y. 1994. The management of soil physical properties limiting crop production in Australian sodic soils - a review. Austr. J. Soil Res. 32(1), 13-44.

Jeschke, W.D. 1984. K+-Na+ exchange at cellular membranes, intracellular compartmentation of cations, and salt tolerance, in: Staples, R.C. (Ed.), Salinity Tolerance in Plants: Strategies for Crop Management. Wiley, New York, pp. 37-66.
Jordan, M.M., Navarro-Pedreno, J. Garcia-Sanchez, E. Mateu, J. Juan, P. 2004. Spatial dynamics of soil salinity under arid and semi-arid conditions: geological and environmental implications. Environ. Geol. 45, 448-45.

Kemmler, G. 1983. Modern aspects of wheat manuring, IPI-Bulletin 1. Int. Potash Inst., Basel, Switzerland.

Khattak, R.A., Jarrell, W.M. 1988. Salt induced manganese solubilization in California Soils. Soil Sci. Soc. Am. J. 52, 1606-1611.

Khattak, R.A., Khan, R.U. Jamal, M.J. Tariq, M. 2002. Mechanisms of K supply to maize grown in three soil series of Peshawar Valley. Soil Science Society of Pakistan, 9th International Congress. March 18-20, 2002 NIAB, Faisalabad.

Kinraide, T. 1999. Interactions among $\mathrm{Ca} 2+, \mathrm{Na}+$ and $\mathrm{K}+$ in salinity toxicity: quantitative resolution of multiple toxic and ameliorative effects. J. Exp. Bot. 50, 1495-1505.

Leigh, R.A., Wyn Jones, R.G. 1984. A hypothesis relating critical potassium concentration for the growth and distribution of this ion in the plant cell. New Phytol. 97, 1-13.

Levy, G.J., Torrento, J.R. 1995. Clay dispersion and macro-aggregate stability is affected by exchangeable potassium and sodium. Soil Sci. 160 (5), 352-358.

Levy, G. J., Feigenbaum, S. 1996. The distribution of potassium and sodium between the solution and the solid phase in a ternary $(\mathrm{K}-\mathrm{Na}-\mathrm{Ca})$ system. Austr. J. Soil Res. 34 (5), 749-754.

Maas, E. V., Hoffman, G. J. 1977. Crop salt tolerance- current assessment. U. S. Salinity Lab. Agriculture Research Service, Riverside, California. 
McLean, E.O. 1982. Soil $\mathrm{pH}$ and lime requirement, in: Page et al. (Ed.), Method of Soil Analysis, Part 2, second ed. Am. Soc. Agron. Inc. Madison, WI, USA, pp. 199-208.

Mengel, K., Kirkby, E.A. 2001. Principles of plant nutrition, fifth ed. Kluwer Academic Publications, Dordrecht, p. 849.

Muhammad, D., Khattak, R.A. 2009: Growth and nutrients concentrations of maize in pressmud treated saline-sodic soils. Soil Environ. 28, 145155.

Munns, R. 2002. Comparative physiology of salt and water stress. Plant, Cell Environ. 25 (2), 239-250.

Munns, R., James, R.A. 2003. Screening methods for salinity tolerance: A case study with tetraploid wheat. Plant Soil. 253(1), 201-218.

Qadir, M., Noble, A.D. Oster, J.D., Schubert, S., Ghafoor, A. 2005. Driving forces for sodium removal during phyto-remediation of calcareous sodic and salinesodic soils: A review. Soil Use Mgmt. 21, 173-180.

Rhoades J.D. 1982. Soluble Salts, in: Page et al. (Ed.), Method of Soil Analysis, Part. 2, second ed. Am. Soc. Agron. Inc., Madison, WI, USA.

Richards, L.A. 1954. Diagnosis and Improvement of Saline Alkali Soils. USDA Handbook-60. U.S. Govt. Printing Office, Washington, DC.

Robbins, C.W. 1984. Sodium adsorption ratioexchangeable sodium percentage relationships in a high potassium saline-sodic soil. Irrig. Sci. 5 (3), 173-179.

Römheld, V., Kirkby, E. 2010. Research on potassium in agriculture: needs and prospects. Plant Soil. 335, 155-180.

Rubio, J. S., García-Sánchez, F., Rubio, F., García, A. L., Martínez, V. 2010. The importance of $\mathrm{K}+$ in ameliorating the negative effects of salt stress on peppers. Eur. J. Hort. Sci. 75, 33-41.

Salam, A., Hollington, P.A., Gorham, J., Wyn-Jones, R.G., Gliddon, C. 1999. Physiological genetics of salt tolerance in wheat (Triticum aestivum L.): Performance of wheat varieties, inbred lines and reciprocal F1 hybrids under saline conditions. J. Agron. Crop Sci. 183, 145-156.

Schachtman, D., Liu, W.H. 1999. Molecular pieces to the puzzle of the interaction between potassium and sodium uptake in plants. Trends Plant Sci. 4, 281-287.

Shabala, S., Cuin, T.A. 2008. Potassium transport and salt stress. Physiol. Plant. 133, 651-669.

Sharma, D.P., Rao, K.V.G.K. 1998. Strategy for long term use of saline drainage water for irrigation in semi-arid regions. Soil Till. Res. 48, 287-295.

Sherif, M.A., El-Beshbeshy, T.R., Richer, C. 1998, Response of some Egyptian varieties of wheat (Triticum aestivum L) to salt stress through potassium application. Bulletin, Faculty of Agricultural University, Cairo. 49, 129-151.

Silberbush, M., Ben-Asher, J. 2001. Simulation study of nutrient uptake by plants from soilless cultures as affected by salinity buildup and transpiration. Plant Soil. 233(1), 59-69.

Soil Survey of Pakistan, 2007. Land Resources Inventory and Agricultural Land Use Plan of Kohat District. National Agricultural Land Use Planning, Lahore, Pakistan.

Spark, D.L. 1995. Environmental Soil Chemistry. Academic Press, New York.

Steel, R.G.D.,Torrie, J.H. 1980. Principles and Procedures of Statistics, second ed. McGraw Hill Book Co., New York, USA. 
Thomas, G.W. 1996. Soil $\mathrm{pH}$ and soil acidity, in: Sparks, D.L. (Ed.), Methods of Soil Analysis, Part 3. American Society of Agronomy, WI, USA, pp. $475-490$

Tisdale, S.L., Nelson, W.L., Beaton, J.D. 1985. Soil Fertility and Fertilizers, 4th ed. Macmillan Publication, New York.
Walsh, L., Beaton, J.D. 1977. Soil testing and plant analysis. Soil Science Society of America. Inc., Madison, WI. 